\title{
Vertical Farming Promising Cultivation for Horticultural Crops
}

\author{
Ashish Kumar ${ }^{1}$, Shardulya Shukla ${ }^{3 *}$, Pushkar Dixit ${ }^{2}$, \\ Thupstan Tsewang ${ }^{3}$ and Kaushal Kumar ${ }^{3}$ \\ ${ }^{1}$ Department of Agriculture, Meerut Institute of Technology, Meerut, India \\ ${ }^{2}$ Department of Agriculture, Vishweswaraya Institute of Engineering and Technology, Dadri \\ Greater Noida, U.P., India \\ ${ }^{3}$ Defence Institute of High Altitude Research, DRDO, Chandigarh, India \\ *Corresponding author
}

\section{A B S T R A C T}

\section{Keywords}

Farming techniques, Vertical farming,

Types and deign of vertical farming

Article Info

Accepted:

20 May 2020

Available Online:

10 June 2020
The world population is increasing at a steady pace. Since the population is growing so the demand for food supply is also rising. To develop more food, more land is necessary while prime agricultural lands are getting to be scarce and costly. Vertical farming utilizes less distance for growing more food. Unlike traditional farming, he also came up with new farming techniques such as Hydroponics and Aeroponics which has high production of food at less space and more yields (which takes less time).

\section{Introduction}

Vertical Cultivation in easy words is, 'farms piled (stacked) together with one another unlike traditional flat farming'. We could even specify Vertical Cultivation since the custom of creating food and medication from vertically stacked layers, previously vertically inclined surfaces or incorporated into various structures. Some farmers or entrepreneurs are starting to employ Vertical Cultivation by utilizing abandoned warehouses, flat rooftops, and lands which are unfertile and futile for farming to make vegetables, fruits, vegetables, and leafy vegetables with high returns. In Vertical Cultivation, it entails growing plants in piled layers reaching to a number of stories packed with controlled environments like temperature, light, and nutrition in inside. This idea of farming is largely used in small residential houses in Indian urban areas, while to make commercially it needs to be seriously regarded as this brand new farming technologies is growing quickly in developed nations. 
Vertical farming represents a proactive thinking approach that aims to ensure the sustainability of cities by addressing the issue of food security. The urban population already faces food shortages, and food prices are skyrocketing due to increases in oil prices, shortages of water and the diminishment of other agricultural resources. The current practices of supplying food to urban areas suffer from environmental and economic problems, such as the inefficient practice of transporting food great distances. As an answer to these problems, the vertical farm will grow food adroitly and sustainably by saving energy, water, and fossil fuels, reducing toxins and restoring ecosystems, as well as providing new opportunities for employment. We have seen the rapid growth of modest-scale vertical farming, and these projects have provided excellent examples of adaptive reuse of vacant industrials spaces.

\section{Types of vertical cultivation}

Vertical farms come in different designs, patterns, and sizes. In developed nations, Vertical Cultivation is done in multi-storied buildings and huge warehouses, therefore, make it simple 2-level or multi-levels or perhaps wall mounted, Vertical Cultivation could be done based on the dimensions, form, and levels of the accessible place. Basically, all types of vertical farms utilize growing mediums and soil-free growing like hydroponics, aquaponics, or aeroponic systems.

\section{Hydroponic vertical cultivation}

This is the most widely growing system employed in Vertical Cultivation. Within this method, the soil is replaced with growing medium like perlite, coconut fiber, coco peat, Rockwool, gravel, and etc. Plants grow by providing nutrient water into the plant roots. The plant roots are enclosed in a mailbox using a substrate and will be hanging directly into the nutrient water. Roots draw nutrients and water directly from the water or out of water consumed substrates in the containers. The water must be regularly monitored for the correct nutrient composition.

\section{Aeroponics vertical cultivation}

This system involves growing plants in misting surroundings with no growing medium or soil and hardly any water containing nutrients. Aeroponics systems are something that deviates from the standard or normal hydroponic farming methods from the Vertical Cultivation Earth, yet they are drawing in huge intrigue. An aeroponics system is by a wide margin the most productive plant developing system for perpendicular cultivation, utilizing something like 90 percent less water than any among the best hydroponic systems. Plants which have been developed in aeroponics systems have likewise been looked to take-up more vitamins and minerals, which makes the plants more healthful and conceivably more nutritious.

\section{Aquaponics vertical cultivation}

In this system, it's a growing combination of both fish and plants at the exact same ecosystem. Fish are grown in huge containers, the waste generated by seeds which turn out to nitrates and ammonia for plants growth. The fish waste becomes a fantastic fertilizer for plant and that they suck up these nutrients from the water thus purifying the water that's delivered back to the massive container in which fish are living. Though, this kind of system is not much widely utilized in Vertical Cultivation as most entrepreneurs focus on producing few fast-growing profitable vegetable crops. Some of the vertical farm entrepreneurs comprise aquaponics but at a smaller-scale based on the primary product line. 
Plan and design of vertical cultivation system

\section{The shape of building for vertical cultivation}

Shape of the construction has a significant part as it ought to get maximum sunlight penetration within through the day. Asymmetrical high rise building is much favored as it isn't hard to plan design and build. Each floor must accommodate six beds with a pathway of approximately 150 to 200 $\mathrm{cm}$ for simple movement of equipment from place to place needed for farming.

\section{Irrigation for vertical cultivation}

Drip irrigation remains the very best irrigation system which saves water by allowing water to drip slowly directly on the plant root zone. The elements required for water to reach the root canal include - water pump, water filters, fertigation systems, backwash controller, pressure control valve, pipes, and tubing. Liquid fertilizer or nutrients with irrigation water provided through drip irrigation can save as much as $95 \%$ in fertilizers. Drip irrigation that's properly designed, installed, managed, will help to reduce water savings.

\section{Lighting system for vertical cultivation}

Lighting can be provided with the natural sunshine system and artificial lighting system. Having a network of Reflectors installed on each floor will enable to use maximum sunlight during daytime. By night light can be done with light emitting diode system which is relatively affordable, bright, and longlasting.

\section{Benefits of vertical cultivation}

Key sustainable benefits have to be summarized in Table 1 (Orsini et al., 2014).

Table.1

\begin{tabular}{|c|c|c|c|c|}
\hline S. No & Benefit & Environmental & Social & Economic \\
\hline 1 & $\begin{array}{l}\text { Reducing food-miles } \\
\text { (travel distances) }\end{array}$ & $\begin{array}{l}\text { Reducing air } \\
\text { pollution }\end{array}$ & $\begin{array}{l}\text { Improving air quality improves } \\
\text { environmental and people's } \\
\text { health. Customers receive } \\
\text { "fresh" local food }\end{array}$ & $\begin{array}{l}\text { Decrease energy, } \\
\text { packaging, and fuel to } \\
\text { transport food }\end{array}$ \\
\hline 2 & $\begin{array}{c}\text { Reducing water } \\
\text { consumption for food } \\
\text { production by using high- } \\
\text { tech irrigation systems and } \\
\text { recycling methods }\end{array}$ & $\begin{array}{l}\text { Reducing surface } \\
\text { water run off of } \\
\text { traditional farms }\end{array}$ & $\begin{array}{l}\text { Making potable water available } \\
\text { to more people }\end{array}$ & Reduce costs \\
\hline 3 & Improve productivity & Needs less space & $\begin{array}{l}\text { Reduce redundant, repetitive } \\
\text { work, and save time to do } \\
\text { productive and socially } \\
\text { rewarding activities }\end{array}$ & Offer greater yields \\
\hline 4 & $\begin{array}{l}\text { Reduced fertilizers, } \\
\text { herbicides, and pesticides }\end{array}$ & $\begin{array}{l}\text { Improve the } \\
\text { environmental } \\
\text { well-being }\end{array}$ & $\begin{array}{l}\text { Improve food quality and } \\
\text { subsequently consumers' health }\end{array}$ & Decrease costs \\
\hline 5 & Using renewable energy & $\begin{array}{l}\text { Reducing fossil } \\
\text { fuel }\end{array}$ & Improve air quality & Reduce costs \\
\hline 6 & $\begin{array}{l}\text { Reducing the activities of } \\
\text { traditional farming }\end{array}$ & $\begin{array}{l}\text { Preserving natural } \\
\text { ecological system }\end{array}$ & Improve health of citizens & $\begin{array}{c}\text { Saving money required } \\
\text { to correct environmental } \\
\text { damage }\end{array}$ \\
\hline
\end{tabular}




\section{References}

Birkby, J. 2016. Vertical farming. ATTRA sustainable agriculture. NCAT IP516, 12.

Caplow, T. 2009. Building integrated agriculture: Philosophy and practice. Urban Futur. 2030: 54-58.

Cicekli, M. and Barlas, N. T. 2014. Transformation of today greenhouses into high technology vertical farming systems for metropolitan regions. $J$. Environ. Prot. Ecol. 15(4): 1779-1785.

Despommier, D. 2014. Encyclopedia of Food and Agricultural Ethics (Vertical Farms in Horticulture). Dordrecht: Springer Netherlands.

Doron, G. 2005. Urban agriculture: Small, medium, large. Architectural Design, 75(3), 52-59.

Ellis, J. 2012. Agricultural Transparency: Reconnecting Urban Centres with Food Production. Master's Thesis, Dalhousie University, Halifax, NS, USA.

Kim, H.G., Park, D.H., Chowdhury, O.R., Shin, C.S., Cho, Y.Y. and Park, J.W. 2014. Location-Based Intelligent Robot Management Service Model Using RGPSI with AOA for Vertical Farm. Lect. Notes Electr. Eng. 279, 309-314.
Liu, X. 2014. Design of a Modified Shipping Container as Modular Unit for the Minimally Structured \& Modular Vertical Farm (MSM-VF)," (Master's Thesis).Available from Pro Quest Dissertations and Theses database. (UMI No.1573000).

Morrow, R. C. 2008. LED lighting in horticulture. HortScience. 43(7): 19471950.

Orsini, F., Gasperi, D., Marchetti, L., Piovene, C., Draghetti, S., Ramazzotti, S., Bazzocchi, G. and Gianquinto, G. 2014. Exploring the production capacity of rooftop gardens (RTGS) in urban agriculture: The potential impact on food and nutrition security, biodiversity and other ecosystem services in the city of Bologna. Food Secur., in press.

Perez, V. M. 2014. Study of The Sustainability Issue of Food Production Using Vertical Farm Methods in An Urban Environment within The State of Indiana," (Master's Thesis).Available from Pro Quest Dissertations and Theses database. (UMI No.1565090).

Wagner, C.G. 2010. Vertical farming: An idea whose time has come back. Futurist. 44, 68-69.

\section{How to cite this article:}

Ashish Kumar, Shardulya Shukla, Pushkar Dixit, Thupstan Tsewang and Kaushal Kumar. 2020. Vertical Farming Promising Cultivation for Horticultural Crops. Int.J.Curr.Microbiol.App.Sci. 9(06): 2491-2494. doi: https://doi.org/10.20546/ijcmas.2020.906.302 